\title{
Rationale for the Use of New Methods of Investigation of Metabolic Syndrome in the Diagnosis and Treatment of Patients with Broncho-Obstructive Diseases
}

DOI: 10.17691/stm2015.7.4.17

Received March 1, 2015

V.A. Vakhlamov, MD, PhD, Tutor, Department of Internal Diseases Propedeutics;

A.V. Tyurikova, MD, PhD, Associate Professor, Department of Internal Diseases Propedeutics

Nizhny Novgorod State Medical Academy, 10/1 Minin and Pozharsky Square, Nizhny Novgorod, 603005 , Russian Federation

The aim of the investigation was to evaluate the need for further research into features of the morbidity and the course of metabolic syndrome among patients with bronchial asthma (BA) and chronic obstructive pulmonary disease (COPD).

Materials and Methods. We examined 235 patients with BA and 103 patients with COPD. To evaluate their nutritional status we identified the body mass index, waist circumference (WC), the index of "waist circumference/height" (WC/height), and the percentages of adipose tissue and of visceral fat. We also studied the biochemical and immunochemical parameters of their metabolism: the levels of fasting blood glucose, postprandial glucose, glycated hemoglobin ( $\mathrm{HbA1c}$ ), immunoreactive insulin, and C-peptide, together with their lipid profiles.

Results. The metabolic changes identified are typical of patients with BA and COPD. Obesity was observed in $45.5 \%$ of patients with COPD and $62 \%$ of patients with BA. Calculation of the WC/height index, and assessing data obtained using bioelectrical impedance analysis can help optimise the diagnosis of obesity. As patients with BA and COPD are fairly likely to develop dyslipidemia this reveals the need for thorough studies of their lipid profiles that can help in the calculation the levels of apolipoproteins $A_{1}$ and $B$. In both groups a high frequency of diabetes mellitus was registered, reaching $33 \%$ in the group of patients with BA. The identification and diagnosis of diabetes mellitus or of early disorders of carbohydrate metabolism amongst hospitalised patients with BA and COPD is impossible without testing fasting blood glucose and the dynamics of postprandial glucose in addition to determining the level of $\mathrm{HbA} 1 \mathrm{C}$.

Conclusion. Regular screening for metabolic disorders among patients with BA and COPD will enable optimisation of their treatment and could reduce the severity of the diseases, as well as decreasing the risk of cardiovascular, endocrinal or pulmonary mortality.

Key words: metabolic syndrome; bronchial asthma; chronic obstructive pulmonary disease.

Currently, chronic obstructive pulmonary disease (COPD) is considered to be a systemic disease which is often associated with hypertonia, coronary heart disease, osteoporosis, metabolic syndrome (MS) and diabetes mellitus (DM) [1-9]. Underlying factors for this comorbidity include a sedentary lifestyle, long-term smoking, hypoxia, hyperinflation, the circulation of a variety of inflammatory mediators in the blood, activation of lipid peroxidation, endothelial dysfunction and lipid disorders [6]. Furthermore, such systemic inflammation is a common pathogenetic element in COPD, atherosclerosis, endothelial dysfunction and coronary heart disease, being both an indicator of the severity of the disease and a predictor of its progression [6].

Recent studies reveal a high incidence of obesity, MS and DM in patients with bronchial asthma (BA) [10-19]. There are also indications that an association between asthma and obesity is more typical of the female population. This may be connected with the dependence of the course of such diseases on hormonal changes, as well as on the specific interconnection of the mechanisms of these diseases with the initial metabolism of fat tissue specific to women $[16,20]$.
According to Panfilov and Uryasyev [14], in the context of therapy for BA exacerbation in patients with comorbidity, the recovery of the normal parameters of respiratory function is often incomplete as these largely reflect restrictive disorders and the severity of which is directly proportional to the severity of abdominal obesity. Moreover, BA in patients with DM causes unfavorable disorders in the circadian profile of arterial blood pressure (ABP). This impaired circadian rhythm, manifests as insufficient reduction of $A B P$, while there is actually greater variability in this at night. Typical proatherogenic disorders of lipid metabolism in patients with comorbidity are hypertriglyceridemia and increased low density lipoprotein cholesterol (LDL-C).

The most clinically significant feature of the course of asthma in patients with obesity is an observed reduction in the efficacy of basic therapy using inhaled glucocorticoids, which therefore often requires an increased daily dosage of these [19]. Patients with BA and obesity also show tolerance to the effects of bronchodilators [21]. These effects necessitate significantly higher daily dosages of all inhaled medications, resulting in metabolic and cardiovascular

For contacts: Vakhlamov Vladimir Alekseevich, e-mail: mlpu10@mail ru 
side-effects. Thus, for the patients with obesity, the frequency of BA exacerbations that require hospitalisation is increased by a factor of 4 compared to patients with normal body mass indices (BMI) [16].

In recent years, information has appeared indicating the genetic predisposition towards an association of BA with metabolic disorders [2, 13]. In fact, some authors regard the combination of BA and obesity as a distinct disease phenotype [22].

According to GINA, obesity can influence the respiratory function by affecting respiratory mechanics directly as well as by leading to the development of an inflammatory state, therefore supplementing the pattern of genetic, ontogenetic, hormonal and neurogenic mechanisms [11].

Taking into account the mutually aggravating effect of the above conditions, as well as the complexity of supervision of patients with such comorbidity, it is becoming increasingly important to study the prevalence and features of metabolic disorders in patients with BA and COPD.

The aim of the investigation was to evaluate the need for further research into the feature of the morbidity and course of the metabolic syndrome among patients with bronchial asthma and chronic obstructive pulmonary disease.

Materials and Methods. We studied 235 patients who had undergone treatment in City Clinical Hospital No.10 in Nizhny Novgorod, for BA (group 1), and 103 patients treated for COPD (group 2), who displayed different degrees of severity of the diseases. Verification of the BA and COPD diagnoses was based on recommendations derived from GINA and GOLD [3, 11].

The study was performed in accordance with the Helsinki Declaration (accepted in June 1964 (Helsinki, Finland) as reviewed in October 2000 (Edinburgh, Scotland)), and approved by the Ethical Committee of the Nizhny Novgorod State Medical Academy. Each patient confirmed their informed consent.

To evaluate the nutritional status of each patient, we used BMI and waist circumference (WC). Additionally, for more accurate diagnosis of the abdominal distribution of fatty tissue we calculated the index of "waist circumference/height" (WC/height) which, although suggested many years ago [23], is not currently widely used in clinical practice.

Presently, the verification of visceral obesity is based on the use of computer or magnetic-resonance tomography [24]. However, this method is hardly likely to become routine, due to its high cost and the fact that radiologists are looking for a more prioritised pathology in this case. To identify the percentages of total fatty tissue and visceral fat in the body we applied the method of bioelectrical impedance analysis (using a Body Composition Monitor BF 508, OMRON, Japan).

Currently, pulmonologists and endocrinologists are aware that investigation of fasting blood glucose (FG), alone, cannot fully characterise the state of carbohydrate metabolism and its regulation, and that this should therefore not be used as the only screening method for diagnosis of DM. That is why, for the subjects assessed in this study, we thoroughly analysed the levels of postprandial glucose (PPG), glycated hemoglobin (HbA1c), immunoreactive insulin (IRI) and C-peptide. For the immunological tests, the determination of IRI and C-peptide was performed in the morning, on an empty stomach, with an Elecsys 2010 (ROCHE, Switzerland) electrochemiluminescent analyser. To evaluate the level of $\mathrm{HbA} 1 \mathrm{c}$ we used a D-10 (BIO-RAD, USA [25]) automatic analyser. The equipment was tested and certified in accordance with the requirements of the National Glycohemoglobin Standardization Program (NGSP).

In our evaluation of the lipid profile we went beyond determining total cholesterol (C), triglycerides, low, very low and high density lipoprotein cholesterol (LDL-C, VLDL-C and HDL-C) and the coefficient of atherogenicity (CAT). All patients were also tested for apolipoproteins $A_{1}$ and $B\left(A p o-A_{1}\right.$ and Apo-B) in addition to calculating their Apo- $A_{1} / A p o-B$ index, since this is as important as the CAT index. Diagnosis of MS was based on the recommendations of the Russian Cardiological Society (2013) [24].

Statistical analysis was carried out using Minitab 16.2.4. software. Depending on the accuracy of distribution of the criteria for the comparison of unrelated groups, we used both the T-test and the Mann-Whitney test, while for related groups, we used the T-test and the Wilcoxon test. When comparing frequencies in independent samples we used the chi-square test $\left(\chi^{2}\right)$ and the accurate Fisher-Irvin method. The data are represented as $\mathrm{Me} \pm \mathrm{m}$ and $\mathrm{Me}$ [25; 75].

Results and Discussion. High importance was attached to the study of the nutritional status of patients with broncho-obstructive diseases [1, 3] (Table 1). It was found that patients with COPD had statistically lower values of $\mathrm{BMl}$ and $\mathrm{WC} /$ height index $(\mathrm{p}=0.002$ and 0.000 , respectively), as well as a lower percentage of fatty tissue $(0.0000)$ when compared to patients with BA. We believe that this is connected with systemic effects in COPD and a high frequency of the emphysematous phenotype of the disease. The high frequency of visceral obesity in the BA group could be caused by aggressive therapies, both the basic ones and those used for treating exacerbations. Furthermore, this pattern could be associated with a genetic predisposition to a combination of BA and obesity. It should be noted that the WC/height index in patients with BA and COPD was a more sensitive criterion of abdominal-visceral obesity than the WC parameter alone, and can be recommended as a screening method for the diagnosis of MS in this category of patients.

Investigation into the frequency of obesity showed that it is typical of $45.5 \%$ of patients with COPD and of $62 \%$ of patients with BA $\left(\chi^{2}=7.57 ; p=0.006\right.$; Fisher $\left.=0.004\right)$ 
(Figure 1). Thus patients with COPD more often had normal or excessive body mass (31.0 and $23.5 \%$, respectively), while, in patients with BA, excessive body mass, and obesity stage I, were typical (23 and $28 \%$, respectively).

The parameters of lipid homeostasis in patients with BA and COPD differed significantly. Hypercholesterolemia and an increase in the level of LDL-C were particularly characteristic of patients with broncho-obstructive diseases. As can be seen from Table 2, the mean totals of $C$ in the BA group was significantly higher $(p=0.035)$. Furthermore, patients with BA had a statistically more significant increase in LDL-C, and the levels of their structural apolipoproteins were accompanied by increases in HDL-C and Apo- $A_{1}$ when compared to patients with COPD. The values of the CAT and Apo$A_{1} / A p o-B$ indices were approximately equal in the groups being considered.

Thus, patients with bronchoobstructive pathology need a more thorough study of their lipid profiles, with a determination of the maximum number of possible parameters, including those of the structural apolipoproteins of lipoproteins as these play an important role. The Apo- $\mathrm{A}_{1} / \mathrm{Apo}-\mathrm{B}$ index can be recommended for study as an equivalent to CAT. The results of the study of the lipid profile show a need for the optimisation of therapy for comorbid pathology with broncho-obstructive diseases, by including statins and fibrates.

The study showed that disorders in the lipid profile were typical of an absolute majority of patients with BA

Table 1
Evaluation of the nutritional status of patients with bronchial asthma and chronic obstructive pulmonary disease

\begin{tabular}{lccc}
\hline \multicolumn{1}{c}{ Parameter } & Bronchial asthma & $\begin{array}{c}\text { Chronic obstructive } \\
\text { pulmonary disease }\end{array}$ & p \\
\hline Body mass index $\left(\mathrm{kg} / \mathrm{m}^{2}\right)$ & $31.79 \pm 6.89$ & $29.24 \pm 6.97$ & $\mathbf{0 . 0 0 2}$ \\
\hline Waist circumference $(\mathrm{cm})$ & $106.18 \pm 15.6$ & $103.18 \pm 16.25$ & 0.112 \\
\hline Waist circumference/height & $0.65 \pm 0.09$ & $0.61 \pm 0.09$ & $\mathbf{0 . 0 0 0}$ \\
\hline Percentage of fatty tissue & $42.75[35.65 ; 49.92]$ & $29.2[18.17 ; 37.57]$ & $\mathbf{0 . 0 0 0 0}$ \\
\hline Percentage of visceral fat & $13[11 ; 15]$ & $13[7.75 ; 17.0]$ & 0.750 \\
\hline
\end{tabular}

$\mathrm{N}$ o t e. The data are represented as $\mathrm{Me} \pm \mathrm{m}$ and $\mathrm{Me}[25 ; 75]$.

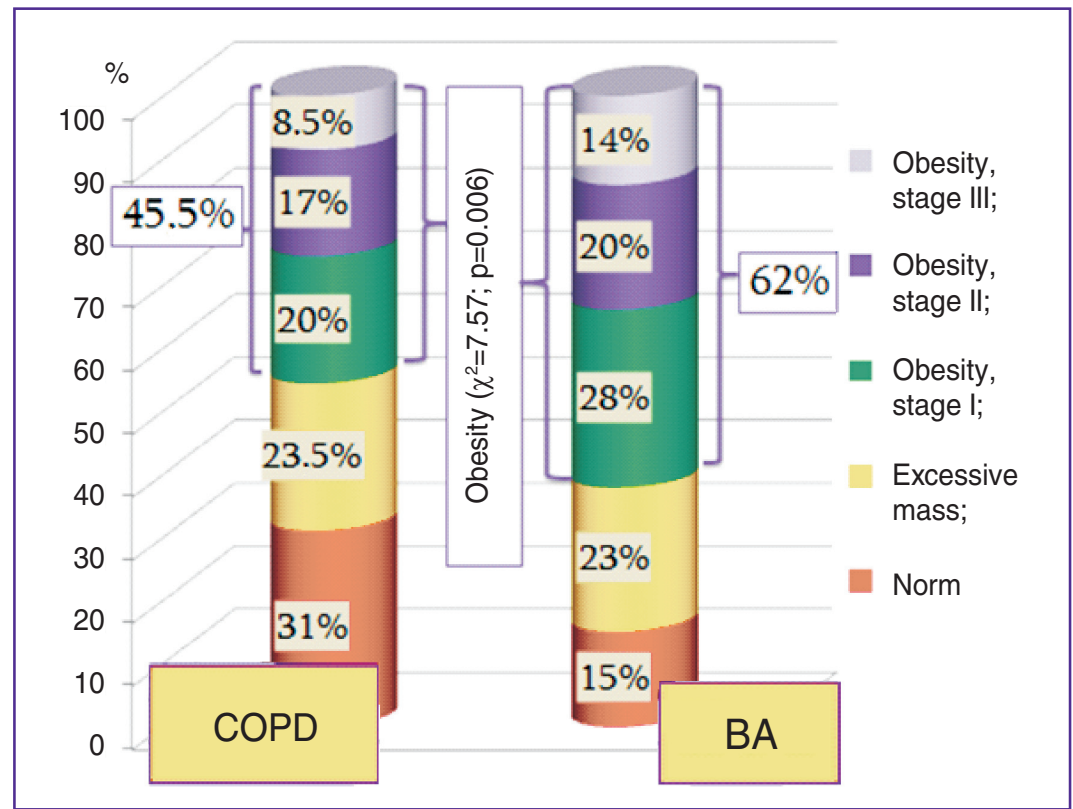

Figure 1. Prevalence of obesity among hospitalised patients with bronchial asthma (BA) and chronic obstructive pulmonary disease (COPD)

and COPD, and this coincides with the findings of other researchers [14]. At the same time, increased cholesterol

Table 2

Features of the lipid profile of patients with bronchial asthma and chronic obstructive pulmonary disease

\begin{tabular}{|lccc}
\hline \multicolumn{1}{c}{ Parameter } & Bronchial asthma & $\begin{array}{c}\text { Chronic obstructive } \\
\text { pulmonary disease }\end{array}$ & p \\
\hline Cholesterol $(\mathrm{mmol} / \mathrm{L})$ & $6.07 \pm 1.25$ & $5.75 \pm 1.44$ & $\mathbf{0 . 0 3 5}$ \\
\hline Triglycerides $(\mathrm{mmol} / \mathrm{L})$ & $1.43[1.04 ; 2.03]$ & $1.48[1.15 ; 2.08]$ & 0.408 \\
\hline HDL-C $(\mathrm{mmol} / \mathrm{L})$ & $1.47[1.22 ; 1.69]$ & $1.31[1.08 ; 1.56]$ & $\mathbf{0 . 0 0 9}$ \\
\hline LDL-C $(\mathrm{mmol} / \mathrm{L})$ & $3.80 \pm 0.96$ & $3.57 \pm 1.09$ & $\mathbf{0 . 0 4 3}$ \\
\hline CAT & $3.21 \pm 1.01$ & $3.36 \pm 1.21$ & 0.345 \\
\hline Apo-A $(\mathrm{g} / \mathrm{L})$ & $1.41 \pm 0.19$ & $1.27 \pm 0.21$ & $\mathbf{0 . 0 0 0}$ \\
\hline Apo-B $(\mathrm{g} / \mathrm{L})$ & $1.12 \pm 0.25$ & $0.99 \pm 0.21$ & $\mathbf{0 . 0 0 0}$ \\
\hline Apo-A $/ \mathrm{Apo}-\mathrm{B}$ & $1.26[1.09 ; 1.47]$ & $1.29[1.07 ; 1.51]$ & 0.638 \\
\hline VLDL-C $(\mathrm{mmol} / \mathrm{L})$ & $0.72[0.51 ; 0.97]$ & $0.78[0.58 ; 1.01]$ & 0.174 \\
\hline
\end{tabular}

$\mathrm{N}$ o t e. The data are represented as $\mathrm{Me} \pm \mathrm{m}$ and $\mathrm{Me}[25 ; 75]$. 


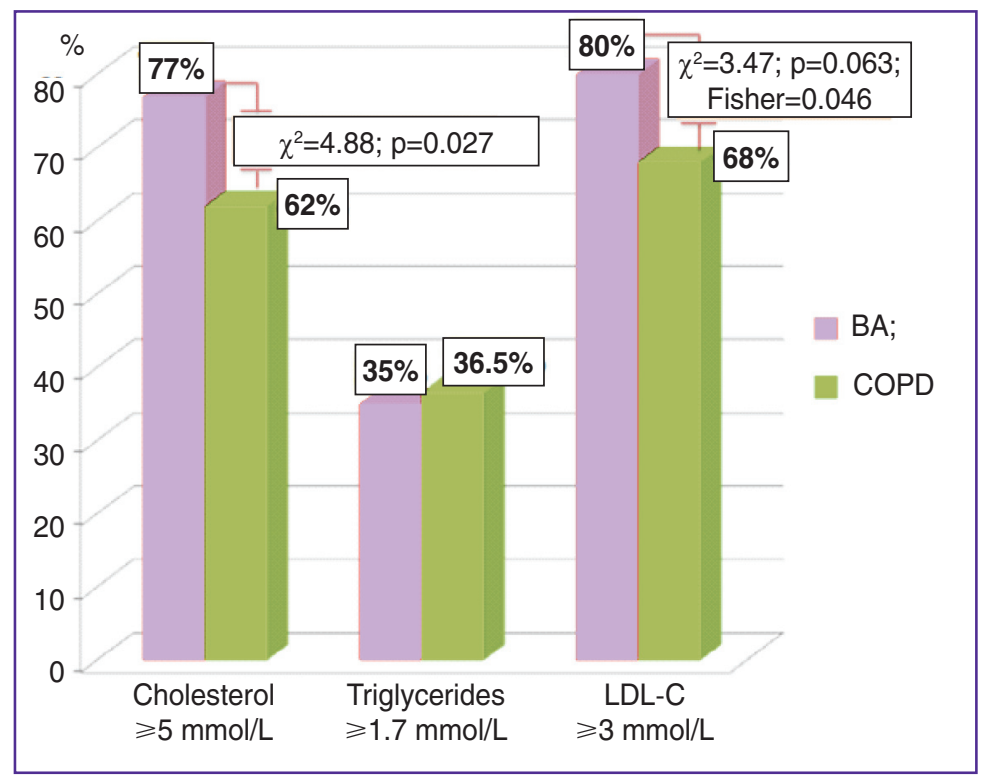

Figure 2. Frequency of dyslipidemia among patients with bronchial asthma (BA) and chronic obstructive pulmonary disease (COPD). LDL-C: low density lipoprotein cholesterol

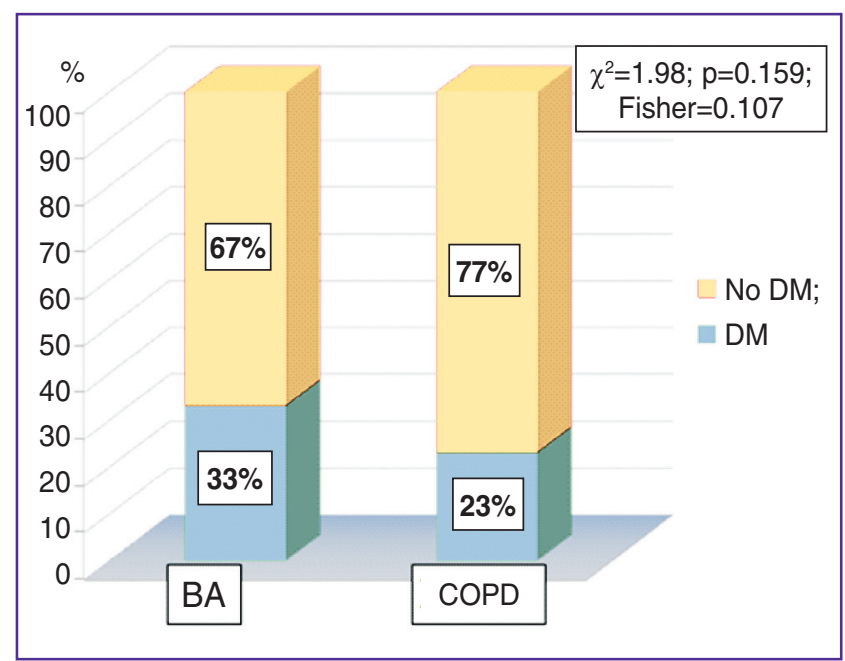

Figure 3. Frequency of diabetes mellitus (DM) among hospitalised patients with bronchial asthma (BA) and chronic obstructive pulmonary disease (COPD) and LDL-C were more frequent in BA (Figure 2). On the whole, hypertriglyceridemia was not a frequent event in broncho-obstructive diseases, occurring in only 35.0 and $36.5 \%$ of the BA and COPD groups, respectively.

In both groups, a high frequency of DM was registered, and for patients with BA it reached 33\% (previously diagnosed + first time diagnosis) (Figure 3). However the differences amongst the groups did not reach a statistically significant level $\left(\chi^{2}=1.98 ; p=0.159\right.$; Fisher=0.107).

Analysing the average values of the parameters of carbohydrate metabolism and its regulation, when patients with BA and COPD were considered separately, other tendencies depending on the presence of DM could be identified. However, there were practically no significant differences between the groups (Table 3). The average values of $\mathrm{HbA} 1 \mathrm{c}, \mathrm{IRI}$, and $\mathrm{C}$-peptide turned out to be higher in patients with DM, though in most cases these tendencies were not statistically significant.

Table 3

Indicators of carbohydrate metabolism and its regulation in patients with bronchial asthma and chronic obstructive pulmonary disease

\begin{tabular}{lccccc}
\hline \multicolumn{1}{c}{ Parameter } & \multicolumn{2}{c}{ Bronchial asthma } & \multicolumn{2}{c}{ Chronic obstructive pulmonary disease } \\
\cline { 2 - 5 } & Without diabetes mellitus & Diabetes mellitus & Without diabetes mellitus & Diabetes mellitus \\
\hline HbA1c $(\%)$ & $6.07[5.7 ; 6.3]$ & $7.7[6.6 ; 8.8]$ & $6.1[5.8 ; 6.4]$ & $7.8[6.4 ; 8.5]$ \\
\hline Fasting blood glucose $(\mathrm{mmol} / \mathrm{L})$ & $5[4.3 ; 5.8]$ & $7.35[5.87 ; 9.47]$ & $4.9[4.3 ; 5.6]$ & $7.3[5.1 ; 9.35]$ \\
\hline Postprandial glycemia $(\mathrm{mmol} / \mathrm{L})$ & $6.31 \pm 1.99^{*}$ & $9.99 \pm 3.66$ & $7.30 \pm 2.37^{*}$ & $9.49 \pm 4.12$ \\
\hline Immunoreactive insulin $(\mu \mathrm{ME} / \mathrm{ml})$ & $17.07[11.21 ; 29.71]$ & $22.09[14.88 ; 37.04]$ & $18.19[10.44 ; 32.36]$ & $26.88[18.48 ; 45.45]$ \\
\hline C-peptide $(\mathrm{ng} / \mathrm{ml})$ & $4.73[3.5 ; 6.19]$ & $5.08[3.49 ; 5.69]$ & $4.86[3.53 ; 6.56]$ & $5.04[4.02 ; 9.29]$ \\
\hline
\end{tabular}

$\mathrm{N}$ o t e. The data are represented as $\mathrm{Me} \pm \mathrm{m}$ and $\mathrm{Me}[25 ; 75] .{ }^{*}$ statistically significant difference between the value for the groups with patients with bronchial asthma and that for chronic obstructive pulmonary disease, $p=0.011$. 
Nevertheless, it should be mentioned that an absolute majority of patients with broncho-obstructive pathology, and even of those without previously diagnosed DM, had hyperinsulinemia, indicating a high frequency of MS.

Statistically significant is the increased PPG in the COPD group compared to the BA group, amongst those patients without previously diagnosed DM $(p=0.011)$. It is likely that the PPG level that can be considered a predictor of the early development of carbohydrate disorders in this group.

In hospitalised patients with BA and COPD we can often observe increased glycemia. However, in our opinion it could be a mistake immediately to diagnose DM or early disorders of carbohydrate metabolism. The fact is, that the intake of glucocorticoids or the administration of other medications against a background of BA and/ or COPD exacerbation, leads logically to an increase in glycemia (including that found in the results of glucose tolerance tests) and it is therefore not informative [26]. This is why, in most cases, if there is no ketoacidosis but a high level of $\mathrm{HbA1c}$, we refrain from prescribing hypoglycemic agents. The parameters of glycemia are controlled dynamically. In most cases, against a background of respiratory failure, and an inflammatory process in the bronchi, a decrease in the dose of systemic glucocorticoids results in the blood sugar level returning to normal.

The glycemia values of hospitalised patients with BA and COPD are of particular scientific interest (Table 4). During the treatment of our patients having BA, there was typically a rapid reduction in blood glucose - both the fasting blood glucose, and the postprandial levels. It is remarkable that, on days $3-5$ of treatment, the $F G$ and PPG values in patients having $B A$, but without previously diagnosed DM, were statistically lower compared to the levels on their first day in hospital $(p=0.003$ and $\mathrm{p}=0.001$ ). In the case of concomitant DM, there was also a statistically significant decrease in $F G(p=0.021)$. In the COPD group the changes in the glycemia parameters were slower. Thus, on days 3-5 of hospitalisation the level of FG was significantly decreased in the subgroup of patients without previously diagnosed DM. Evidently, in some cases, when the parameters of glycemia did not return to normal, the patients were prescribed hypoglycemic agents, and even insulin. In the opposite case, if doctors prescribed even minimal doses of "antidiabetic" medications to the hospitalised BA and COPD patients who had normal values of $\mathrm{HbA} 1 \mathrm{c}$ and slightly increased values of their glycemic profile, we faced the problem of frequent, recurrent, apparent cases of hypoglycaemia, which occurred mainly after the elimination of exacerbation, and the termination of glucocorticoids.

Thus, the issues of diagnosing DM or early disorders of carbohydrate metabolism should be considered individually. At the same time we should thoroughly analyse the values of the glycemic profile, $\mathrm{HbA} 1 \mathrm{c}$, and the levels of IRI and of C-peptide.

In any case, analysis of the data we had obtained testifies to a high risk of DM starting against a background of exacerbation of broncho-obstructive diseases, especially of COPD. This is probably connected with the systemic inflammatory process occurring in this disease, severe ventilation disorders and tissue hypoxia.

The frequency of MS in patients with BA reached $85 \%$, while in the COPD group it was $61 \%\left(\chi^{2}=15.94\right.$; $\mathrm{p}=0.0001$ ) which seems quite logical, and is mainly due to a decrease in the nutritional status parameters as a manifestation of the systemic effect of this disease.

Conclusion. Metabolic disorders are fairly common

Table 4

Dynamics of glycemia parameters among hospitalised patients with bronchial asthma and chronic obstructive pulmonary disease

\begin{tabular}{lccc}
\hline \multicolumn{1}{c}{ Parameter (mmol/L) } & $\begin{array}{c}\text { Measurement 1 (day 1) } \\
\text { Bronchial asthma }\end{array}$ & Measurement 2 (days 3-5) & p \\
\hline $\begin{array}{l}\text { Without diabetes mellitus: } \\
\text { fasting blood glucose }\end{array}$ & $6.6[5.85 ; 7.55]$ & $5.1[4.35 ; 5.90]$ & $\mathbf{0 . 0 0 3}$ \\
postprandial glycemia & $6.85[6.02 ; 7.47]$ & $5.05[4.32 ; 5.47]$ & $\mathbf{0 . 0 0 1}$ \\
$\begin{array}{l}\text { Diabetes mellitus: } \\
\text { fasting blood glucose }\end{array}$ & $8.51 \pm 2.53$ & $7.37 \pm 3.21$ & $\mathbf{0 . 0 2 1}$ \\
postprandial glycemia & $11.41 \pm 3.23$ & $10.52 \pm 3.62$ & 0.094 \\
\hline & Chronic obstructive pulmonary disease & & \\
Without diabetes mellitus: & & & \\
fasting blood glucose & $7.43 \pm 2.52$ & $5.72 \pm 1.66$ & $\mathbf{0 . 0 0 4}$ \\
postprandial glycemia & $8.36 \pm 2.3$ & $7.90 \pm 2.86$ & 0.459 \\
Diabetes mellitus: & & & \\
fasting blood glucose & $8.61 \pm 3.31$ & $8.18 \pm 4.70$ & 0.623 \\
postprandial glycemia & $11.02 \pm 4.28$ & $12.50 \pm 5.13$ & 0.261 \\
\hline
\end{tabular}

$\mathrm{N}$ o t e. The data are represented as $\mathrm{Me} \pm \mathrm{m}$ and $\mathrm{Me}[25 ; 75]$. 
in patients with BA and COPD so their control should be taken into account during the treatment of these diseases. More accurate diagnosis of abdominal-visceral obesity can be based on calculation of the index of "waist circumference/height" as well as on data obtained from bioelectrical impedance analysis.

For a deeper investigation of the lipid profile, with identification of the maximum number of possible parameters, including the important part played by the structural apolipoprotein components of lipoproteins, we suggest using the coefficient of Apo- $A_{1} / A p o-B$, since it can be recommended as an equivalent of the coefficient of atherogenicity.

Identification of DM or early disorders of carbohydrate metabolism among hospitalised patients with BA and COPD is impossible without the results of tests on fasting blood glucose, the dynamics of postprandial glycemia, and determination of the level of $\mathrm{HbA1c}$. Any high values of blood glucose found in hospitalised patients, in this case, should be interpreted individually. The only reliable criteria for identifying carbohydrate disorders in this situation would be a high level of $\mathrm{HbA} 1 \mathrm{c}$ and/or ketoacidosis. Exacerbations of broncho-obstructive diseases, mainly COPD, are a significant risk factor in the development of diabetes mellitus.

A thorough study of metabolic syndrome and all its components would allow more informed and rationalised therapies to be developed for comorbid diseases, considerably reducing the general severity of the disease as well as lowering the risks of suffering cardiovascular, endocrine or pulmonary mortality.

Study Funding. This study was not supported by any financial sources.

Conflict of Interest. The authors have no conflicts of interest to disclose.

\section{References}

1. Avdeev S.N. Khronicheskaya obstruktivnaya bolezn' legkikh [Chronic obstructive pulmonary disease]. Moscow: Izdatel'skiy kholding "Atmosfera"; 2010; 160 p.

2. Astaf'eva N.G., Gamova I.V., Udovichenko E.N., Perfilova I.A. Obesity and bronchial asthma. Lechashchiy vrach 2014; 5: 100 .

3. Global'naya strategiya diagnostiki, lecheniya i profilaktiki khronicheskoy obstruktivnoy bolezni legkikh (peresmotr 2011 g.) [Global strategy of diagnosis, treatment and prevention of chronic obstructive pulmonary disease (updated 2011)]. Pod red. Belevskogo A.S. [Belevskiy A.S. (editor)]. Moscow: Rossiyskoe respiratornoe obshchestvo; 2012.

4. Popova T.N. Osobennosti kliniko-laboratornykh proyavleniy i nutritivnogo statusa $u$ bol'nykh KhOBL $v$ sochetanii $s$ metabolicheskim sindromom. Avtoref. dis. ... kand. med. nauk [Features of clinical laboratory manifestations and nutritional status in patients with COPD in combination with metabolic syndrome. PhD Thesis]. Tyumen; 2009.

5. Ryazanov A.S., Kireev S.A., Eremenko N.N. Influence of the body mass index on the spirography parameters in patients with COPD in combination with metabolic syndrome. Biomeditsina 2010; 4: 119-121.
6. Sokolova S.Yu. Klinicheskie, immunologicheskie i bakteriologicheskie proyavleniya khronicheskoy obstruktivnoy bolezni legkikh na fone ozhireniya. Dis. ... kand. med. nauk [Clinical, immunological and bacteriological manifestations of chronic obstructive pulmonary disease complicated by obesity. DSc Dissertation]. Samara; 2007.

7. Smetneva N.S., Vikentiev V.V., Zavyalova S.A., Popkova A.M., Malishev I.Y. Role of inflammatory factors in the development of cardiovascular pathology in chronic obstructive pulmonary disease. Fundamentalnie issledovania 2013; 3: 162-166.

8. Chuchalin A.G. Chronic obstructive pulmonary disease and comorbidities. Part I. COPD and diseases of the cardiovascular system. Russkij medicinskij zurnal 2008; 16(2): 58-64.

9. Mannino D.M., Thorn D., Swensen A., Holguin F. Prevalence and outcomes of diabetes, hypertension, and cardiovascular disease in COPD. Eur Respir $J$ 2008; 32(4): 962-969, http://dx.doi.org/10.1183/09031936.00012408.

10. Antonovich Zh.V., Oleynik T.S., Starovoytova S.O., Tsarev V.P. Disorders of lipid metabolism in patients with bronchial asthma and dose maintenance therapy with inhaled glucocorticosteroids. Meditsinskaya panorama 2009; 6: 6-12.

11. Global'naya strategiya lecheniya $i$ profilaktiki bronkhial'noy astmy (peresmotr 2011 g.) [Global strategy for asthma management and prevention (updated 2011)]. Pod red. Belevskogo A.S. [Belevskiy A.S. (editor)]. Moscow: Rossiyskoe respiratornoe obshchestvo; 2012.

12. Ermolova A.V., Budnevskiy A.V., Drobysheva E.S. Bronchial asthma and metabolic syndrome: clinical-pathological relations. Molodoy uchenyy 2014; 6: 291-294.

13. Nagornyy A.B. Osobennosti narusheniya uglevodnogo obmena u bol'nykh bronkhial'noy astmoy. Avtoref. dis. ... kand. med. nauk [Features of disorders in the carbohydrate metabolism of patients with bronchial asthma. PhD Thesis]. Moscow; 2004.

14. Panfilov U.A., Uryasiev O.M. Clinicofunctional and laboratory features of the course of bronchial asthma among patients with metabolic syndrome. Rossiyskiy medikobiologicheskiy vestnik im. akademika I.P. Pavlova 2008; 4: 85-99.

15. Uryas'ev O.M., Panfilov Yu.A. Bronchial asthma and metabolic syndrome: some aspects of comorbidity. Mezhdunarodnyy endokrinologicheskiy zhurnal 2008; 3(15): 15-25.

16. Tsibulkina V.N., Tsibulkin N.A. Asthma and obesity: coincidence or pattern? Prakticheskaya meditsina 2011; 6(54): 36-41.

17. Brenner J.S., Kelly C.S., Wenger A.D., Brich S.M., Morrow A.L. Asthma and obesity in adolescents: is there an association? J Asthma 2001; 38(6): 509-515, http://dx.doi. org/10.1081/jas-100105872.

18. Beyther D.A., Sutherland E.R. Over weight, obesity and incident asthma: a meta-analysis of prospective epidemiologic studies. Am J Resp Crit Care Med 2007; 175: 661-667, http:// dx.doi.org/10.1164/rccm.200611-17170C.

19. Saint-Pierre P., Bourdin A., Chanez P., Daures J.P., Godard P. Are overweight asthmatics more difficult to control. Allergy 2006; 61(1): 79-84, http://dx.doi.org/10.1111/j.13989995.2005.00953.x.

20. Sood A., Qualls C., Li R., Schuyler M., Beckett W.S., Smith L.J., Thyagarajan B., Lewis C.E., Jacobs D.R.; CARDIA Investigators. Lean mass predicts asthma better than fat mass among females. Eur Respir J 2011; 1(37): 65-71, http://dx.doi. org/10.1183/09031936.00193709. 
21. Yeh K.H., Skowronski M.E., Coreno A.J., Seitz R.E., Villalba K.D., Dickey-White H., McFadden E.R. Impact of obesity on the severity and therapeutic responsiveness of acute episodes of asthma. J Asthma 2011; 8(6): 546-552, http:// dx.doi.org/10.3109/02770903.2011.581733.

22. Yashina L.A., Ishchuk S.G. Bronchial asthma in patients with obesity - a specific phenotype of the disease. Astma ta alergiya 2011; 4: 46-49.

23. Kovaleva O.N. Obesity and the risk of cardiovascular pathology in women. Zdorov'ya Ukraini 2009; 9(26).

24. Proekt rekomendatsiy ekspertov rossiyskogo kardiologicheskogo obshchestva po diagnostike i lecheniyu metabolicheskogo sindroma (3-y peresmotr) [Draft Recommendations of experts from the russian society of cardiology for the diagnostics and treatment of metabolic syndrome ( $3^{\text {rd }}$ updated)]. Moscow; 2013; 103 p.

25. Likhonosova A.P., Likhonosov N.P., Kuznetsova O.G. Analysis of methods for determining the level of glycosylated hemoglobin as used in health care facilities in Saint Petersburg. Mezhdunarodnyy endokrinologicheskiy zhurnal 2010; 6(30): 23-27.

26. Ametov A.S. Sakharnyy diabet 2 tipa. Problemy $i$ resheniya [Diabetes mellitus type 2. Problems and solutions]. Moscow: GEOTAR-Media; 2011; 704 p. 